\title{
Bruk av rusmidler er \\ utbredt hos personer \\ med psykoselidelse
}

Når helsepersonell kartlegger pasientenes sykdom, er det nødvendig å spørre hver enkelt om deres bruk av rusmidler og hvilken funksjon bruken har.

Henning Pettersen

Førsteamanuensis

Fakultet for helse- og sosialvitenskap, Høgskolen i Innlandet

Kvalitativ studie

Psykisk lidelse

Stoffmisbruk

rus

Rusmiddel

Sykepleien 2020108 (80910) (e-80910)

DOI: 10.4220/Sykepleiens.2020.80910

\section{Hovedbudskap}

Personer med alvorlig psykisk lidelse er mer tilbøyelige til å bruke rusmidler enn andre, og de skårer lavt på viktige levekårsindekser. Men vi vet fortsatt lite om hvorfor og hvordan personer med psykoselidelse ruser seg. Deltakerne i denne studien brukte rusmidler for å mestre livet, kontrollere symptomer, motvirke bivirkninger av medikamenter og balansere ambivalens. De фnsket å bli rusfrie på grunn av frykt for å bli avhengig og rusens negative påvirkning på sosiale relasjoner og fordi rusen skapte avstand til personer og steder.

Profesjonelle helsearbeidere spør sjelden hvorfor og hvordan pasienter med alvorlige psykiske lidelser bruker rusmidler når det er grunn til å tro at de gjør det. 
I denne artikkelen, som bygger på mitt doktorgradsarbeid fra 2015, redegjør jeg for hvilke erfaringer en gruppe pasienter med psykoselidelse og samtidig ruslidelse i opps $\varnothing$ kende behandling har med rusmidler.

\section{Vi vet lite om psykoselidelse og rusbruk}

Personer med alvorlig psykisk lidelse er mer tilbøyelige til å bruke rusmidler enn andre $(1,2)$. Internasjonal forskning viser at disse personene skårer dårligere enn andre på viktige levekårsindekser (3), er vanskelige å få i behandling og har en tendens til å droppe ut av behandlingen (4).

Behandling av personer med samtidig ruslidelse og psykisk lidelse (ROP-lidelse) gjøres både i psykisk helsevern, i tverrfaglig spesialisert rusbehandling (TSB) og til en viss grad i kommunene.

Selv om vi vet mye om de skadelige virkningene av rusmidler, finnes det også forskning som viser at visse rusmidler i et gitt omfang har en positiv effekt for brukerne dersom de ikke bruker det for ofte, og ikke bruker for sterke rusmidler (5).

Men vi vet fortsatt lite om hvorfor og hvordan personer med psykoselidelse ruser seg. Er det tilfeldig hvilke rusmidler de bruker, i hvilke mengder, og hvor ofte de bruker det? Og er det slik at personer med en spesifikk psykiatrisk diagnose foretrekker bestemte typer rusmidler fremfor andre?

\section{Stadig flere får behandling i ACT-team}

Som en del av regjeringens satsing på samhandling i psykisk helsefeltet bevilget Helse- og omsorgsdepartementet gjennom statsbudsjettet for 2010 midler til opprettelse og drift av Assertive Community Treatment-team (ACT-team) i Norge.

I løpet av perioden 2008-2012 startet departementet opp 14 slike team. Parallelt startet en forskningsbasert evaluering av disse teamene. Evalueringen viste at de som var inkludert i ACT, hadde redusert behov for innleggelser på sykehus og ble i mindre grad enn ved annen behandling underlagt tvangsvedtak (6).

I de påfølgende årene har stadig flere med ROP-lidelser fått behandling og oppfølging i ACT-team eller Flexible Assertive Community Treatment-team (FACT-team), som har blitt et satsingsområde for helsemyndighetene. 


\section{De fleste hadde en psykisk lidelse først}

Denne studien hadde et deskriptivt og eksplorativt design med en fenomenologisk tilnærming. Den handlet om forskningsdeltakernes livserfaringer og er beskrevet i tidligere arbeider (7-9).

Jeg gjennomførte til sammen 20 individuelle intervjuer med et utvalg av brukere $(\mathrm{n}=11)$ med ROP-lidelse inkludert norske ACT-team. Inklusjonskriteriene var oppnådd bedring på områdene livskvalitet og/eller funksjonsnivå og/eller rusmiddelbruk etter minimum tolv måneder i behandling.

\section{$\equiv$ ¿Flesteparten brukte flere typer rusmidler, men hadde ikke utviklet avhengighet.»}

Deltakerne var ni menn og to kvinner i alderen 27-63 år. De fleste var diagnostisert med schizofreni eller schizoaffektiv lidelse, men det var også deltakere med bipolar og uspesifisert psykoselidelse. For de fleste av deltakerne hadde den psykiske lidelsen vært fremtredende før de begynte med rusmidler.

Flesteparten brukte flere typer rusmidler, men hadde ikke utviklet avhengighet. De rusmidlene som deltakerne benyttet hyppigst, var cannabis og amfetamin. Også alkohol ble benyttet, men i noe mindre grad.

\section{Alle deltakerne bodde alene}

De fleste ruset seg tre-fire ganger per uke, ofte i sammenheng med $\varnothing$ kte symptomer på den psykiske lidelsen. Fire av deltakerne hadde sluttet helt med rusmidler.

Alle bodde alene, de fleste $\mathrm{i}$ en bolig de leide gjennom kommunen, mens to av deltakerne eide leiligheten de bodde $i$. Fire av deltakerne var i lønnet arbeid, enten i praksisplass gjennom Nav eller annet tilrettelagt tilbud. De $\varnothing$ vrige var helt eller delvis uføretrygdet.

Jeg gjennomførte individuelle intervjuer hjemme hos deltakerne eller i et egnet møterom i ACT-teamets lokaler. Intervjuene hadde en varighet på om lag en time. Deretter analyserte jeg den transkriberte teksten fra intervjuene med systematisk tekstkondensering (10). 


\section{Forholdet til rus var motsetningsfylt}

Deltakerne i studien hadde et motsetningsfylt forhold til rusmidler. På den ene siden ga rusmidler dem positive opplevelser og var en måte å mestre den psykiske lidelsen på.

På den andre siden hadde de fleste også negative erfaringer med bruk av rusmidler og hadde etablert strategier for å kutte ut eller redusere bruken.

Hovedtemaene og undertemaene jeg kom frem til i studien, kan vi se i figur 1.

Figur 1. Hovedtemaer og undertemaer som kom frem under analysen.

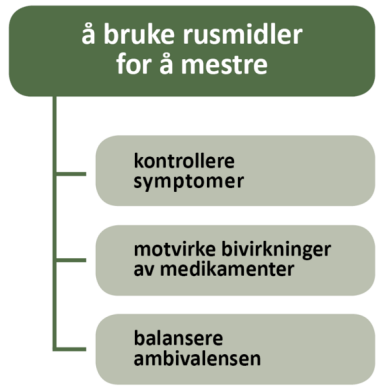

å bli rusfri

frykt for å utvikle

avhengighet

sosiale relasjoner

avstand til personer og arenaer

\section{Alkohol dempet angst og depresjon}

Jeg undersøkte hvordan ulike emosjonelle tilstander ble påvirket av rusmidler. Noen av deltakerne som brukte eller hadde brukt alkohol regelmessig, forklarte at hensikten med alkoholbruken var å dempe angst og depresjon og ta en pause fra alt som var vanskelig i livet.

\section{三 «Noen mente at alkohol var mindre skadelig enn illegale rusmidler.»}

Noen mente at alkohol var mindre skadelig enn illegale rusmidler. Andre uttrykte en forkjærlighet for cannabis eller amfetamin og omtalte alkohol i negative ordelag ved at den ofte skaper større problemer både for enkeltindivider og på samfunnsnivå.

Årsakene de oppga for å bruke rusmidler, var at det både var en måte å unnslippe ubehagelige tilstander på og en mulighet til å fokusere på noe annet. De forklarte dette ved hjelp av uttrykk som pause, avbrudd eller flukt.

Noen hadde utviklet strategier for å innarbeide slike «timeouts» i sin hverdag, mens det skjedde mer vilkårlig for andre. 


\section{Cannabisbruk mildnet indre stemmer}

En av deltakerne (mann, 45 år) var diagnostisert med paranoid schizofreni og hadde brukt alkohol i mange år som en bevisst strategi for å håndtere angst og depressive tanker:

«Det går en periode på 24 dager, og så kommer det 12 øl som stopper det vanskelige [...] som en pause. Og det er å være et annet sted fordi du er full. Altså, da er jeg er fornøyd når jeg begynner på blanke ark og fortsetter 24 dager til. Og så kommer det tolv $\varnothing 1$ [...] og så går jo livet sånn, da. Så får du jo kanskje en takk av Gud eller et eller annet fordi du har greid det.»

Flere av deltakerne anså bruk av cannabis som en måte å håndtere indre stemmer på. I de fleste tilfellene kunne cannabisbruk mildne påvirkningen av høye og dominerende eller befalende stemmer.

\section{Amfetamin kunne regulere maniske faser}

Bruken av amfetamin så ut til å ha mange funksjoner. Et anvendelsesområde var å regulere eller initiere maniske faser ved bipolar lidelse. De av deltakerne dette gjaldt, forklarte at mani som var fremskyndet av amfetamin, var lettere å håndtere enn andre maniske episoder.

Fordi kontroll og stabilitet er viktig ved en bipolar lidelse, så de på amfetamin som et virkemiddel til å få hyppigere maniske faser, men at fasene var mindre dramatiske enn uten påvirkning av amfetamin.

Amfetamin syntes å være det foretrukne rusmiddelet når det gjaldt å håndtere plagsomme bivirkninger av antipsykotika. Vektøkning og medfølgende inaktivitet ble rapportert av mange av deltakerne som hadde brukt slike medikamenter.

\section{Antipsykotika gjorde deltakerne søvnige}

Flere av deltakerne uttrykte at de hadde behov for flere våkne dager siden antipsykotika gjorde dem sløve og søvnige. Det gjorde at de fikk en utpreget trang til å sove både dag og natt.

En av deltakerne (mann, 33 år) var diagnostisert med en schizoaffektiv lidelse og hadde brukt ulike antipsykotika i en årrekke: 
«Jeg sto på Zyprexa, da fikk jeg angst og sov veldig mye. Det var da amfetaminbruken min begynte, så det har nok litt å gjøre med virkningen av antipsykotisk medisin. Jeg husker at jeg sov så mye... at jeg ønsket meg en dag eller en helg i måneden hvor jeg var våken.»

Deltakernes årsaker til å bruke rusmidler handlet også om ambivalens og tvil. Det samme rusmiddelet kunne ha forskjellige betydninger, virkninger og konsekvenser for ulike personer.

\section{Bruk av rusmidler kunne skape problemer}

I et overordnet perspektiv anerkjente deltakerne den positive korttidsvirkningen av rusmidlene, men samtidig var de bevisst på skadelige langtidsvirkninger. Bruk av rusmidler kunne skape problemer, men likevel bidro de til at deltakerne fungerte bedre på mange arenaer.

Noen deltakere hadde erfart at spesielt amfetamin ga dem $\varnothing \mathrm{kt}$ energi og livslyst, men at de senere kunne få ubehagelige skjelvinger og oppleve betydelig nedstemthet.

\section{三 «Behovet for rusmidler syntes å være mindre påtrengende når symptomer på den psykiske lidelsen ikke var dominerende.»}

En deltaker (mann, 40 år) slet med overvekt og hadde brukt både amfetamin og cannabis for å gå ned i vekt. Han mente at det kunne være en hårfin balansegang. Han forklarte:

«Jeg husker at amfetamin gjorde at jeg gikk raskt ned i vekt, men etter hvert ble det ikke noe behagelig. Noen ganger har jeg brukt cannabis fordi det ikke har den umiddelbare effekten. Det er best å gjøre det gradvis. Jeg håper å stabilisere vekten på et akseptabelt nivå slik at jeg kan føle et slags velvære.»

Alle deltakerne brukte rusmidler for å håndtere episoder som oppsto på grunn av den psykiske lidelsen. Behovet for rusmidler syntes å være mindre påtrengende når symptomer på den psykiske lidelsen ikke var dominerende. 


\section{Mange fryktet mer alvorlig rusmisbruk}

Rusmidlene kunne være til hjelp for å mestre noen plagsomme symptomer knyttet til deltakernes psykiske lidelse på kort sikt, men de fleste deltakerne innså at langtidsvirkningen av rusmidlene var negativ. De innså at det var viktig å kunne redusere eller slutte med rusmidler.

Mange uttrykte redsel for å utvikle toleranse overfor rusmidler og en mulig overgang til mer alvorlig rusmisbruk. De anså injisering av heroin som det farligste.

For de fleste deltakerne var en overgang fra rusmisbruk til avhengighet et symbol på en alvorlig forverring av selvbildet, noe som syntes å bidra til at noen hadde klart å kutte ut bruken av rusmidler. En av deltakerne (mann, 40 år), som for det meste hadde brukt alkohol, uttrykte seg slik:

«Det beste er egentlig å holde seg unna alkoholen fordi hvis du har drukket i mange år, vil det fortsatt fremstå som en fristelse, både drikking og bruk av andre rusmidler. Du har et toleransenivå. Denne veien starter i det små, og etter hvert blir det heroin. Hasj ligger omtrent i midten. Så målet må være å ikke begi seg ut på den veien eller stake ut en annen kurs før det er for sent.»

\section{Deltakerne slet med avholdenhet}

Deltakerne fryktet å miste kontrollen på rusbruken og bli så påvirket at det forverret den psykiske lidelsen. Likevel ble perioder med avholdenhet opplevd som vanskelig for flere av dem fordi de ofte kjente på følelser som utilstrekkelighet og frykt.

Det syntes som om fraværet av rusen ledet til både positive og negative opplevelser. Alle deltakerne hadde erfart perioder med avholdenhet, men de fleste hadde ikke vært avhengig av rusmidler. Flertallet mente at de hadde et gjennomgående bedre funksjonsnivå når de holdt seg unna rusmidler.

\section{三 «Det å være i et forhold dempet behovet for rusmidler.»}

Relasjonelle faktorer var innbefattet i de fleste betingelsene for å klare å slutte med rusmidler. Aktiviteter med ulike formål og i ulike kontekster ble ofte nevnt og assosiert med forholdet til andre mennesker. 
De fleste av deltakerne hadde erfart at å gjenopprette bånd med familie og nære venner og være i stand til å delta $i$ dagliglivets aktiviteter var helt avgjørende.

Mange av årsakene deltakerne oppga for å bli rusfrie, handlet om betydningen av sosiale relasjoner og å unngå isolasjon og ensomhet. Argumentene var at man måtte være edru for å finne en partner, og at å være i et forhold dempet behovet for rusmidler.

\section{Deltakerne unngikk tidligere rusmiljøer}

De fleste av deltakerne fortalte om den negative innflytelsen fra tidligere rusmiljøer. For å unngå å vende tilbake til tidligere venner i rusmiljøene var det avgjørende for dem å motstå trangen til å gjenopps $\varnothing$ ke disse miljøene.

Det fungerte ikke å innta en slags «mellomholdning». Det var enten-eller. En deltaker (mann, 43 år) hadde vært inn og ut av rusinstitusjoner mange ganger og hadde etter hvert utviklet en strategi for å stå imot rustrangen:

«Jeg hadde ommøblert leiligheten, slik at det var annerledes å komme hjem den siste gangen, fordi jeg har opplevd å komme hjem på permisjon når alt $\mathrm{i}$ leiligheten minnet meg om mitt tidligere liv, og jeg ble fristet til å ruse meg igjen. Den siste gangen fikk jeg ikke slike tanker i det hele tatt og har klart å holde meg rusfri siden.»

\section{Rusmiddelbruken hadde ulike formål}

Deltakerne i studien ruset seg hovedsakelig for å håndtere vanskelige følelser og plagsomme symptomer på en alvorlig psykisk lidelse. De samme rusmidlene ble brukt til ulike formål for ulike personer.

For eksempel ble amfetamin brukt som et beroligende middel i forbindelse med plagsomme indre stemmer, for å kompensere for emosjonell avflating og som et slankemiddel. Deltakerne som uttalte dette, hadde en psykoselidelse.

Funnene fra studien støtter den tradisjonelle selvmedisineringshypotesen (11) fordi spesifikke rusmidler ble brukt for å håndtere plagsomme symptomer, ubehagelige følelser eller dysfori. 
Disse funnene avviker imidlertid fra andre studier som har unders $\varnothing \mathrm{kt}$ pasientenes perspektiver, der det kom frem at bruk av rusmidler hovedsakelig hadde en negativ effekt på psykoselidelsen $(12,13)$. Det er imidlertid uklart hva som er plagsomme symptomer, ubehagelige følelser og dysfori (14).

\section{Få hadde negative erfaringer med rus}

Det som skiller funnene i de ovennevnte studiene fra denne studien, er at deltakerne primært hadde en ruslidelse, mens deltakerne i denne studien hadde utviklet en psykoselidelse over flere år med påfølgende rusmisbruk.

Et annet viktig aspekt kan være at flertallet av deltakerne i denne studien rapporterte få negative erfaringer med bruk av rusmidler, antakelig fordi de fleste av dem ikke hadde utviklet avhengighet.

\section{三 «Deltakerne vektla å ta det riktige rusmiddelet på riktig måte for å redusere skadelige effekter.»}

Et annet fremtredende funn i denne studien var at deltakerne vektla å ta det riktige rusmiddelet på riktig måte for å redusere skadelige effekter. I så henseende var amfetamin det hyppigst benyttede rusmiddelet.

Forskningslitteraturen sier lite om hvordan utbredelsen av amfetamin og andre stimulerende midler er blant personer med psykoselidelser, og hvordan midlene brukes.

Det er få studier som omhandler hvordan personer med psykoselidelser bruker og erfarer virkningen av slike rusmidler, selv om det finnes eldre studier som har funnet at personer med schizofreni har lettere for å utvikle aktiv psykose ved bruk av stimulerende midler enn personer med andre psykiske lidelser

(15).

\section{De færreste klarte å bli rusfrie}

Få deltakere i denne studien hadde klart å bli rusfrie. En mulig forklaring er at de fleste av dem, som tidligere nevnt, ikke hadde utviklet avhengighet og heller ikke ruset seg daglig. Mange hadde derfor ikke opplevd alvorlige skadevirkninger av sitt rusmiddelbruk. 
Noen av dem som var avholdende, og noen av dem som fortsatt ruset seg, men hadde initiert rusfrie perioder, uttalte at frykten for å bli avhengig eller psykotisk var et argument for å kutte ut rusen.

Frykt for å utvikle avhengighet som en motivasjon for avholdenhet er ikke gjenfunnet i andre studier, selv om det er rapportert om negative konsekvenser av rusen som motivasjon for å bli rusfri $(12,16)$.

De overnevnte studiene skilte seg imidlertid fra denne studien ved at de omhandlet deltakere med gjennomgående tungt rusmiddelmisbruk.

\section{Støttende nettverk har stor betydning}

Mine resultater indikerer at deltakernes ruserfaringer kombinert med psykisk lidelse ga dem en bevissthet om at langsiktig eller kortsiktig avholdenhet fra rusmidler var viktig for å opprettholde stabilitet i livet.

Et hovedfunn i denne studien var at deltakerne måtte ta avstand fra sitt tidligere rusmiljø for å oppnå rusfrihet. Dette samsvarer med resultatene fra Davis og O'Neills studie, som også unders $\varnothing$ kte deltakernes strategier for å bli rusfrie (17).

Andre kvalitative studier med utvalg som ikke var direkte sammenliknbare med denne studien, identifiserte imidlertid ikke avstand som strategi for å bli rusfri $(16,18,19)$.

Flere av deltakerne i denne studien viste til betydningen av å kutte ut rusmiddelbruken for å finne en partner og komme ut av isolasjonen. Betydningen av et støttende sosialt nettverk var fremtredende, og til en viss grad ble behandlere i ACT ansett som en del av nettverket.

En gradvis bevisstgjøring om at rusmiddelbruk kom i konflikt med et vanlig liv og personlig velbefinnende, var fremtredende hos deltakerne. Flere kvalitative studier har konkludert med at st $\varnothing t t e n d e$ nettverk hadde mest å bety for at personer med psykoselidelse kunne oppnå rusfrihet (2022). 


\section{Rusmiddelbruk ble ikke ansett som misbruk}

Henwood og medarbeideres casestudie identifiserte tre begivenheter som bidro til at personer klarte å kutte ut rusmiddelbruken: vendepunkter $\mathrm{i}$ livet, gradvis modning og institusjonsbehandling (18). Denne studien var sammenliknbar med min studie bortsett fra at deltakerne hadde vært rusfrie over lengre tid.

Å finne den rette balansen og gjenvinne eller opprettholde stabiliteten var viktig både for dem som fortsatt brukte rusmidler, og hadde eller ikke hadde rusfrie perioder, og for dem som hadde kuttet ut rusmidler.

\section{三 «Deltakerne mente at moderat bruk av alkohol og cannabis var harmløst.»}

De aktive brukerne legitimerte rusmiddelbruken mer som bruk enn misbruk. Deltakerne mente at moderat bruk av alkohol og cannabis var harmløst. Det meste av ambivalensen var knyttet til bruk av amfetamin, som flere av deltakerne hadde både gode og dårlige erfaringer med.

Ut fra funnene kan det se ut som om mennesker med psykoselidelse ofte opplever motstridende følelser knyttet til sin bruk av rusmidler (13). Samtidig kan det å bli rusfri være både besværlig og konfliktfylt (16). For mennesker både med og uten alvorlig psykisk lidelse har rusen flere ansikter.

\section{Behandlere må spørre om rusmiddelbruk}

Når det gjelder selvmedisinering, bør behandlere være oppmerksomme på at pasientene kan anvende rusmidler for å lindre symptomer på psykisk lidelse, og at spesifikke rusmidler kan brukes for å motvirke både positive og negative symptomer på psykoselidelse.

Når helsepersonell kartlegger pasientenes sykdom, er det nødvendig å spørre hver enkelt om deres bruk av rusmidler og hvilken funksjon bruken har.

Slik kartlegging bør også ta i betraktning om rusmiddelbruken har foranlediget psykisk sykdom, eller vice versa. Nettopp det kan ha innvirkning på pasientenes syn på rusmidlenes funksjon. 


\section{Hvorfor trenger pasientene rusmidler?}

Behandlere trenger å motivere brukere til å redusere rusmiddelbruken, og brukere trenger hjelp til å håndtere angst og depresjon. Hvordan man kan leve med å høre indre stemmer, blir også viktig i behandlingen.

Ved kartlegging av rusmiddelbruk er det like viktig å spørre om hvordan og hvorfor pasientene bruker rusmidler, som hvilket rusmiddel de benytter.

Ved behandling med antipsykotika bør behandlere nøye vurdere bivirkningene av medikasjonen. Noen personer med psykoselidelse synes å ha bedre livskvalitet når de bruker rusmidler enn når de er avholdende.

I noen grad kan det innebære å jobbe sammen med brukerne for å minimere snarere enn å eliminere rusmiddelbruken, og behandlere bør i større grad være bevisst på slike forhold.

\section{Referanser}

1. Hartz S, Pato C, Medeiros H, Cavazos-Reg P, Sobell J, Knowles J, et al. Comorbidity of severe psychotic disorders with measures of substance use. Jama Psychiatry. 2014;71(3):248-54. DOI: 10.1001/jamapsychiatry.2013.3726

2. Hasin D, Kilcoyne B. Comorbidity of psychiatric and substance use disorders in the United States: current issues and findings from the NESARC. Curr Opin Psychiatry. 2012;25(3):165. DOI: 10.1097/yco.obo13e3283523dcc

3. Padgett DK, Smith BT, Henwood BF, Tiderington E. Life course adversity in the lives of formerly homeless persons with serious mental illness: context and meaning. Am J Orthopsychiatry. 2012;82(3):421-30. DOI: 10.1111/j.19390025.2012.01159.x

4. Fredwall TE. En oppsummering av kunnskap. Pasientforløp for personer med samtidig ruslidelse og psykiske lidelse. Oppsummering nr. 10. Omsorgsbiblioteket; 2018.

5. Wagstaff C. Towards understanding the self-perception of people with psychotic illness who use illicit substances and have a history of disengagement from mental health services: qualitative research. Int J Psychiatr Nurs Res.

2007;12(3):1503-20. 
6. Landheim A, Ruud T. Evaluering av ACT-team.

Sluttrapport: Nasjonal kompetansetjeneste for rus- og psykisk lidelse. Lørenskog: Akershus universitetssykehus; 2014.

7. Pettersen H, Ravndal E, Ruud T, Landheim A. Searching for sobriety: How persons with severe mental illness experience abstaining from substance use. J Addict Res Ther. 2014;5(4). DOI: $\underline{10.4172 / 2155-6105.1000193}$

8. Pettersen H, Ruud T, Ravndal E, Landheim A. Walking the fine line: Self-reported reasons for substance use in persons with severe mental illness. Int J Qual Stud Health Well-being. 2013;8:21968. DOI: 10.3402/qhw.v8io.21968

9. Pettersen H. Erfaringer med rusmiddelbruk og opps $\varnothing$ kende behandling hos personer med psykoselidelse. (Doktorgradsavhandling.) Oslo: Universitetet i Oslo; 2015.

10. Malterud K. Systematic text condensation: a strategy for qualitative analysis. Scand J Public Health. 2012;40(8):795805. DOI: $\underline{10.1177 / 1403494812465030}$

11. Khantzian E. The self-medication hypothesis of substance use disorders: a reconsideration and recent applications. Harv Rev Psychiatry. 1997;4(5):231-44. DOI: $\underline{10.3109 / 10673229709030550}$

12. Charles V, Weaver T. A qualitative study of illicit and non-prescribed drug use amongst people with psychotic disorders. J Ment Health. 2010;19(1):99-106. DOI:

10.3109/09638230802523039

13. Cruce G, Øyehagen A, Nordstrøm M. Experiences of alcohol and other drugs in individuals with severe mental illness and concomitant substance use disorders. Mental health and Substance use: dual diagnosis. 2008;1(3):228-41. DOI: $\underline{10.1080 / 17523280802317404}$

14. Henwood B, Padgett D. Re-evaluating the selfmedication hypothesis among the dually diagnosed. Am J Addict. 2007;16(3):160-5. DOI: 10.1080/10550490701375368

15. Lieberman J, Kane J, Alvir J. Provocative tests with psychostimulant drugs in schizofrenia. Psychopharmacology. 1987;91(4):415-33. DOI: 10.1007/bfoo216006 
16. Laudet A, Magura S, Vogel H, Knight E. Perceived reasons for substance misuse among persons with a psychiatric disorder. Am J Orthopsychiatry. 2004;74:365-75. DOI: $\underline{10.1037 / 0002-9432.74 \cdot 3 \cdot 365}$

17. Davis KE, O'Neill SJ. A focus group analysis of relapse prevention strategies for persons with substance use and mental disorders. Psychiatr Serv. 2005;56(10):1288-91. DOI: 10.1176/appi.ps.56.10.1288

18. Henwood B, Padgett D, Smith B, Tiderington E. Substance abuse recovery after experiencing homelessness and mental illness: case studies of change over time. J Dual Diagn. 2012;8(3):238-46. DOI: 10.1080/15504263.2012.697448

19. Asher C, Gask L. Reasons for illicit drug use in people with schizophrenia: qualitative study. BMC psychiatry. 2010;10:94. DOI: 10.1186/1471-244X-10-94

20. Alverson $\mathrm{H}$, Alverson M, Drake R. Social patterns of substance-use among people with dual diagnoses. Ment Health Serv Res. 2001;3(1):3-14. DOI: 10.1023/a:1010104317348

21. Gomez M, Primm A, Tzolova-Iontchev I, Perry W, Hong T, Crum R. A description of precipitants of drug use among dually diagnosed patients with chronic mental illness. Community Ment Health J. 2000;36(4):351-62.

22. Thommesen H. Hverdagsliv, selvforståelse og dobbeltdiagnose - om mennesker med uvanlige erfaringer. (Doktorgradsavhandling.) Bodø: Høgskolen i Bod $\varnothing ; 2008$. 